\title{
ZAKAT PRODUKTIF UNTUK PEMBERDAYAAN EKONOMI UMAT
}

\author{
Ahmad Thoharul Anwar \\ Peneliti Zakat dan Wakaf Kudus \\ e-mail: aa250735@gmail.com
}

\begin{abstract}
The purpose of this study is to know the management of productive zakat for the economic empowerment of society in LAZISNU Kudus. This study uses a qualitative approach and is described descriptively. Data collection techniques used interviews, observation, and documentation. While data analysis using data reduction, data display and verification. From the results of the study concluded that the management of productive zakat funds conducted by LAZISNU Kudus using the stages in management science. The steps in the empowerment of productive zakat by LAZISNU Kudus include data collection, supervision and supervision. There are two obstacles facing LAZISNU, internal and external factors. Among the internal factors are limited funds provided, lack of coordination, lack of adequate human resources and administrative management that is still traditional. While external factors include is still a lot of muzakki who pay zakat outside amil institutions and mustahik less know management business.
\end{abstract}

Keywords: Productive Zakat, Economic Empowerment, LAZISNU. 


\section{Ahmad Thoharul}

\section{Pendahuluan}

Permasalahan yang sering dihadapi oleh negaranegara berkembang adalah masalah ekonomi, termasuk negara Indonesia saat ini. Permasalahan ekonomi sering kali berdampak negatif terhadap kehidupan sosial masyarakat seperti, kemiskinan dan pengangguran. Kemiskinan merupakan permasalahan bagi setiap negara, golongan, sampai pada masing-masing individu (Sanihah, 2014: 2). Pemerintah sebetulnya memiliki program-program yang telah digulirkan dalam rangka menanggulangi bencana ini. Dan salah satu yang menjadi alternatif program pemerintah sebagai sumber dana untuk mengatasi kemiskinan adalah dengan penyaluran zakat. Zakat sangatlah mungkin menjadi alternatif program pemerintah sebagai sumber dana untuk mengatasi kemiskinan. Pembentukan modal tidak semata-mata dari pemanfaatan dan pengembangan sumber daya alam, akan tetapi berasal dari sumbangan wajib orang kaya. Zakat juga berperan penting dalam peningkatan kualitas sumber daya manusia dan penyediaan sarana dan prasarana produksi.

Zakat merupakan salah satu pilar (rukun) dari lima pilar yang membentuk Islam. Zakat adalah ibadah maaliah ijtima'iyyah yang memiliki posisi yang strategis dan menentukan bagi pembangunan kesejahteraan umat (Huda, 2015: 5). Sehingga zakat tidak hanya berfungsi sebagai ibadah yang bersifat vertikal kepada Allah, namun zakat juga berfungsi sebagai wujud ibadah yang bersifat horizontal. Zakat memiliki manfaat yang sangat penting dan strategis dilihat dari sudut pandang ajaran Islam maupun dari aspek pembangunan kesejahteraan umat. Kewajiban membayar zakat, secara sosiologis merupakan manifestasi dari solidaritas sosial. Rasa kemanusiaan yang adil dan bertanggung jawab, kepedulian untuk selalu merasakan apa yang dirasakan oleh orang lain yang sedang mengalami kesusahan hidup. 


\section{Zakat Produktif untuk Pemberdayaan Ekonomi ...}

Di Indonesia yang mayoritas penduduknya bergama Islam sebenarnya memiliki potensi yang strategis dan sangat layak untuk dikembangkan dalam menggerakkan perekonomian negara. Selain itu, konsep zakat yang ditawarkan Islam menjanjikan dimensi kemaslahatan dan pengelolaan potensi sumber daya ekonomi dalam kehidupan masyarakat. Pendekatan transformatif dalam pengembangan ekonomi Islam melalui gerakan zakat sebagai gerakan ekonomi yang berlandaskan syari'ah Islam, merupakan aktualisasi operasional ekonomi Islam dalam mewujudkan kesejahteraan masyarakat. Zakat merupakan wujud pilar perekonomian Islam dalam menjalankan fungsinya untuk mengelola dan menyalurkan dana umat kepada orang-orang yang berhak.

Hal yang sering dipertimbangkan di tengah masyarakat kita adalah kepada siapa zakat harus diberikan. Lebih utama disalurkan langsung oleh muzakki kepada mustahiq, atau sebaliknya melalui amil zakat. Jika disalurkan kepada mustahiq, memang ada perasaan tenang karena menyaksikan secara langsung zakatnnya tersebut telah disalurkan kepada mereka yang dianggap berhak menerimanya. Tapi terkadang penyaluran langsung yang dilakukan oleh muzakki tidak mengenai sasaran yang tepat. Terkadang orang sudah merasa menyalurkan zakat kepada mustahiq, padahal ternyata yang menerimanya bukan mustahiq yang sesungguhnya, seperti hanya karena kedekatan emosi maka ia memberikan zakat kepadanya. Oleh karena itu, untuk menyalurkan zakat dari muzakki untuk mustahiq diperlukan lembaga penyaluran zakat yang mempunyai tugas khusus menjadi amil zakat yakni mengalokasikan, mendayagunakan, mengatur masalah zakat, baik pengambilan maupun pendistribusiannya (Sanihah, 2014: 3).

Salah satunya lembaga yang memberdayakan zakat adalah ormas Nahdhatul Ulama di Kabupaten Kudus 


\section{Ahmad Thoharul}

dengan membentuk organisasi zakat yaitu Lembaga Amal Zakat Infaq dan Sedekah Nahdhatul Ulama (LAZISNU). LAZISNU Kudus merupakan salah satu departemen Nahdlatul Ulama (NU) yang bertugas menghimpun, mengelola dan mentasharufkan zakat infaq dan sedekah kepada mustahiq-nya. Mandat pengelolaan zakat infaq dan sedekah yang diberikan kepada LAZISNU adalah segala hal untuk upaya pengumpulan zakat, infaq dan sedekah yang kemudian menyalurkan kepada mustahiq. Sehingga fungsi LAZISNU itu sendiri adalah perantara antara muzakki dengan mustahiq.

Kegiatan yang dilakukan LAZISNU adalah meliputi penghimpunan dana zakat dan pendistribusian dana zakat. Dalam penghimpunan dana zakat yang dilakukan LAZISNU dalam bentuk fundraising, yang meliputi menemui langsung muzakki, dropbox, media sosial, penyelenggaraan penghimpunan dalam bentuk event, mediasi para tokoh, menjalin relasi, dan sebagainya. Sedangkan dalam aspek pendistribusian dana zakat, sejauh ini terdapat dua pola penyaluran zakat, yaitu pola tradisional (konsumtif) dan pola penyaluran produktif (pemberdayaan ekonomi) (Toriquddin, 2015: 63). Kajian ini akan menganalisis peran zakat untuk pemberdayaan ekonomi umat yang dilakukan oleh LAZISNU.

\section{Pembahasan}

\section{Kajian Zakat}

Menurut syariat, ada dua makna yang terkadung dalam zakat, pertama, sebab dikeluarkannya zakat itu karena adanya proses tumbuh kembang pada harta itu sendiri atau tumbuh kembang pada aspek pahala yang menjadi semakin banyak dan subur disebabkan mengeluarkan zakat. Atau keterkaitan adanya zakat itu semata-mata karena memiliki 
sifat tumbuh kembang seperti zakat tijarah dan Zira'ah. Kedua, pensucian karena zakat adalah pensucian atas kerusakan, kebakhilan jiwa, dan kotoran-kotoran lainnya, sekaligus pensucian jiwa manusia dari dosa-dosanya.

Menurut UU No. 23 tahun 23 Tahun 2011 tentang pengelolaan zakat, zakat adalah harta yang wajib dikeluarkan oleh seorang muslim atau badan usaha untuk diberikan kepada yang berhak menerimanya sesuai dengan syariat Islam. Mathews and Tlemsani dalam Dogarawa menyebutkan zakat merupakan bagian tertentu dari kekayaan yang ditentukan oleh Allah untuk didistribusikan kepada kategori orang yang berhak menerimanya. Ini diwajibkannya kepada orang yang memiliki kelebihan harta kepada orang yang kekurangan harta.

Zakat merupakan salah satu pilar (rukun) dari lima pilar yang membentuk Islam. Zakat adalah ibadah maaliah ijtima'iyyah yang memiliki posisi yang strategis dan menentukan bagi pembangunan kesejahteraan umat. Zakat tidak hanya berfungsi sebagai suatu ibadah yang bersifat vertikal kepada Allah (hablumminallah), namun zakat juga berfungsi sebagai wujud ibadah yang bersifat horizontal (hablumminannas).

\section{Zakat Produktif}

Zakat produktif merupakan model pendistribusian zakat yang dapat membuat para mustahiq menghasilkan sesuatu secara terus menerus, dengan harta zakat yang telah diterima. Zakat produktif adalah harta zakat yang diberikan kepada mustahiq tidak dihabiskan atau dikonsumsi tetapi dikembangkan dan digunakan untuk membantu usaha mereka, sehingga dengan usaha tersebut mustahiq dapat memenuhi kebutuhan hidup secara terus menerus (Toriquddin, 2015). 


\section{Ahmad Thoharul}

Untuk mencapai produktif, maka perlu adanya pengelolaan. Pengelolaan berasal dari kata mengelola yang berarti mengendalikan atau menyelenggarakan. Sedangkan tren pengelolaan berati proses melalukam kegiatan tertentu dengan menggerakkan tenaga orang lain, atau dapat juga diartikan proses pemberian pengawasan pada semua hal yang terlibat dalam pelaksanaan kebijaksanaan dan pencapaian tujuan. Jadi, pengelolaan menyangkut proses suatu aktifitas. Dalam kaitannya dengan zakat, proses tersebut meliputi sosialisasi zakat produktif, pengumpulan zakat, pendistribusian dan pendayagunaan serta pengawasan. Dengan demikian pengelolaan zakat produktif adalah proses dan pengorganisasian sosialisasi, pengumpulan, pendistribusian, dan pengawasan dalam pelaksanaan zakat (Hasan, 2013: 17). Oleh sebab itu diperlukan empat fungsi manajemen yang meliputi perencanaan (planning), pengorganisasian (organizing), penggerakan (actuanting), dan pengawasan (controlling).

\section{Pemberdayaan Ekonomi Masyarakat}

Pemberdayaan ini dimaksudkan untuk berkuasa atau mampu atas dirinya sendiri untuk memenuhi kebutuhannya. Pemberdayaan masyarakat adalah proses pembangunan di mana masyarakat berinisiatif untuk memulai proses kegiatan sosial untuk memperbaiki situasi dan kondisi diri sendiri (Wikipedia.com).

Kegiatan pemberdayaan terdiri dari dua aktivitas yaitu pengumpulan dan pendistribusian zakat. Kegiatan pendistribusian zakat, infaq, dan sedekah dikaitkan dengan atau dijabarkan ke dalam bentuk-bentuk program pemberdayaan ekonomi para mustahiq. Bentuk-bentuk program pemberdayaan tersebut diwujudkan dalam berbagai bentuk pendistribusian zakat. Dalam hal ini, pendistribusian zakat dapat berbentuk zakat konsumtif 
(sembako) atau dirupakan dalam bentuk uang tunai. Zakat juga dapat didistribusikan dalam bentuk beasiswa pendidikan, pelatihan dan pembinaan, program adik asuh, sarana dan prasarana, dan modal usaha produktif.

Zakat yang diberikan kepada mustahiq akan berperan sebagai pendukung peningkatan ekonomi mereka apabila dikonsumsikan pada kegiatan produktif. Pendayagunaan zakat produktif sesungguhnya mempunyai konsep perencanaan dan pelaksanaan yang cermat seperti mengkaji penyebab kemiskinan, ketidakadaan modal kerja, dan kekurangan lapangan kerja, dengan adanya masalah tersebut maka perlu adanya perencanaan yang dapat mengembangkan zakat bersifat produktif tersebut.

Pengembangan zakat bersifat produktif dengan cara menjadikan dana zakat sebagai modal usaha, untuk pemberdayaan ekonomi penerimanya, dan supaya fakir miskin dapat menjalankan atau membiayai kehidupannya secara konsisten. Dengan dana zakat tersebut fakir miskin akan mendapatkan penghasilan tetap, meningkatkan usaha, mengembangkan usaha serta mereka dapat menyisihkan penghasilannya untuk menabung.

Dana zakat untuk kegiatan produktif akan lebih optimal bila dilaksanakan Lembaga Amil Zakat karena LAZ sebagai organisasi yang terpercaya untuk pengalokasian, pendayagunaan, dan pendistribusian dana zakat, mereka tidak memberikan zakat begitu saja melainkan mereka mendampingi, memberikan pengarahan serta pelatihan agar dana zakat tersebut benar-benar dijadikan modal kerja sehingga penerima zakat tersebut memperoleh pendapatan yang layak dan mandiri.

Dengan berkembangnya usaha kecil menengah dengan modal berasal dari zakat akan menyerap tenaga 


\section{Ahmad Thoharul}

kerja. Hal ini berarti angka pengangguran bisa dikurangi, berkurangnya angka pengangguran akan berdampak pada meningkatnya daya beli masyarakat terhadap suatu produk barang ataupun jasa, meningkatnya daya beli masyarakat akan diikuti oleh pertumbuhan produksi, pertumbuhan sektor produksi inilah yang akan menjadi salah satu indikator adanya pertumbuhan ekonomi. Dengan gambaran tersebut, maka peranan zakat sangat signifikan dalam kehidupan manusia. Dimana zakat merupakan suatu penggerak atau motor yang berpotensi memberikan tunjangan kepada para pedagangataupun profesi lain yang membutuhkan modal, yang tidak bisa didapatkan dari jalan lain (Narullah, 2015: 11-12).

Salah satu bentuk usaha mengatasi kemiskinan melalui pendistribusian zakat produktif yang merupakan program pemberdayaan ekonomi. Penyaluran ini berbentuk bantuan modal (berbentuk uang tunai atau barang) untuk berdagang dan peralatan untuk usaha dalam mencari nafkah hidup.

Pendistribusian zakat produktif ini diberikan kepada aktifitas yang dapat menghasilkan manfaat dalam jangka panjang dan melepaskan ketergantungan ekonomi masyarakat miskin dari bantuan pihak lain. Penerima zakat produktif ini harus memenuhi tiga syarat; pertama, sudah mempunyai usaha produktif yang layak. Kedua, bersedia menerima tugas pendamping yang berfungsi sebagai pembimbing dan ketiga, bersedia menyampaikan laporan usaha secara berkala setiap enam bulan (Yusuf, 2017).

Pendistribusian zakat produktif diberikan kepada 8 golongan, diantaranya fakir, miskin, amil, riqab, muallaf, gharimin, fisabilillah, dan ibnu sabil. Pendistribusian zakat produktif di LAZISNU Kudus ditekankan kepada janda miskin. Dimana status sebagai janda miskin adalah termasuk salah satu dalam 8 asnaf, yaitu miskin. 


\section{Zakat Produktif untuk Pemberdayaan Ekonomi ...}

\section{Sejarah LAZISNU Kudus}

Lembaga Amal Zakat Infaq Sedekah Nahdlatul Ulama (LAZISNU) Kudus merupakan salah satu departemen Nahdlatul Ulama (NU) yang bertugas menghimpun, mengelola dan mentasharufkan zakat infaq dan sedekah kepada mustahiq. Mandat pengelolaan zakat infaq dan sedekah yang diberikan kepada LAZISNU adalah segala hal yang upaya pengumpulan zakat infaq dan sedekah yang kemudian menyalurkan kepada mustahiq.

LAZISNU terbentuk pada akhir kepengurusan PCNU Kudus era KH Chusnan periode 2008/2013 tepatnya Oktober 2013 dengan menunjuk Sholichin sebagai Ketua dan Sya'roni Suyanto sebagai Direktur. Pada tanggal 8 Desember 2013 PCNU mengadakan konferensi cabang NU Kudus yang hasilnya mengamanatkan Sya'roni Suyanto menjadi Ketua. LAZISNU Kudus juga telah mengantongi SK dari Pengurus Pusat LAZISNU. LAZISNU Kudus mendeklarasikan namanya sebagai lembaga amal dan bukan lembaga amil. Hal ini berdasarkan pengarahan dewan pengawas syari'ah dan para kiai di Kudus. Sejak mendapat SK LAZISNU semakin giat melakukan penataan lembaga, penguatan jaringan dan menentukan langkah maupun program kerja kedepan.

Pada bulan Juni 2014 SK kepengurusan LAZISNU Kudus dibawah kepemimpinan Sya'roni Suyanto telah turun dari pimpinan pusat LAZISNU. Keberadaan LAZISNU Kudus sangat berbeda dari ketentuan pusat. Dari Namanya, Tahun 2015 sebagai tahun optimisme bagi pengurus LAZISNU Kudus guna mewujudkan impian sebagai lembaga terpercaya dalam mengumpulkan, mendistribusikan serta mendayagunakan dana zakat, infaq dan sedekah (ZIS). Program-program utama LAZISNU yakni NU'Smart, NU'Preneur, NU'Skill dan NU'Care secara perlahan terus digalakkan secara masif melalui bentukbentuk program yang bersentuhan dengan kepentingan keumatan.

Untuk mengembangkan atau memaksimalkan kinerja, LAZISNU Kudus membentu Jaringan Pengelola Zakat, Infak dan 


\section{Ahmad Thoharul}

Sedekah (JPZIS) salah satunya di Kecamatan Dawe dengan nama JPZIS LAZISNU Kecamatan Dawe Kudus dengan memberikan SK Nomor 034/ LAZISNU/V/2016 dan mulai beroperasi pada bulan Desember 2016.

LAZISNU merupakan salah satu departemen NU yang bertugas menghimpun mengelola dan mentasahrufkan zakat, infaq dan sedekah kepada mustahiq. Mandat pengelolaan zakat, infaq dan sedekah (ZIS) yang diberikan kepada LAZISNU adalah segala hal upaya pengumpulan ZIS yang kemudian menyalurkan kepada yang berhak (mustahiq).

Saat ini LAZISNU Kudus sudak eksis menjalankan mandat yang diberikan oleh PCNU Kudus dengan mengacu pada ketentuan yang disepakati oleh pengurus LAZISNU Kudus. Upaya menentukan acuan ini melalui proses perencanaan strategis (strategic planning) lembaga dan pemrograman, selanjutnya hasil perencanaan dan pemrograman menjadi landasan yang di sahkan oleh LAZISNU Kudus untuk dilaksanakan dalam kurun waktu yang ditentukan (LAZISNU, 2018).

\section{Mekanisme Pengelolaan Zakat Produktif di LAZISNU Kudus}

Istilah pengelolaan berasal dari kata mengelola yang berarti mengendalikan atau menyelenggarakan. Sedangkan tren pengelolaan berarti proses melalukan kegiatan tertentu dengan menggerakkan tenaga orang lain, atau dapat juga diartikan proses pemberian pengawasan pada semua hal yang terlibat dalam pelaksanaan kebijaksanaan dan pencapaian tujuan. Dalam kaitannya dengan zakat, proses tersebut meliputi perencanaan, pengorganisasian dan pengawasan (Hasan, 2013: 17).

Kegiatan yang dilakukan LAZISNU adalah meliputi penghimpunan dana zakat dan pendistribusian dana zakat. 


\section{Zakat Produktif untuk Pemberdayaan Ekonomi ...}

Dalam penghimpunan dana zakat yang dilakukan LAZISNU dalam bentuk fundraising, yang meliputi menemui langsung muzakki, dropbox, media sosial, penyelerenggaraan penghimpunan dalam bentuk event, mediasi para tokoh, menjalin relasi, dan sebagainya.

Table berikut adalah data pendistribusian dana zakat dari tahun 2015-2017:

Tabel 1. Pendistribusian Dana Zakat (2015-2017)

\begin{tabular}{|l|l|r|c|c|}
\hline No & Tahun & Non Produktif & Produktif & Jumlah \\
\hline 1 & 2015 & $\operatorname{Rp} 26.121 .600$ & $\operatorname{Rp} 8.000 .000$ & $\operatorname{Rp} 34.121 .600$ \\
\hline 2 & 2016 & $\operatorname{Rp} 55.195 .000$ & $\operatorname{Rp} 3.000 .000$ & $\operatorname{Rp} 58.195 .000$ \\
\hline 3 & 2017 & $\operatorname{Rp} 96.882 .000$ & $\operatorname{Rp} 23.000 .000$ & $\operatorname{Rp} 119.882 .000$ \\
\hline
\end{tabular}

Sumber: Dokumen LAZISNU Kudus 2017

Berdasarkan data diatas, maka pendistribusian zakat di LAZISNU Kudus lebih banyak diberikan kepada program non produktif. Pada tahun 2015, penerima dana zakat produktif sebanyak 8 orang. Pada tahun 2016 diketahui bahwa penerima dana zakat produktif turun menjadi 3 orang dan di tahun 2017 diketahui bahwa penerima dana zakat produktif meningkat menjadi 23 orang. Jumlah keseluruhan dari tahun 2015-2017 bahwa penerima dana zakat produktif sebesar 34 orang.

Mekanisme yang digunakan oleh LAZISNU Kudus dalam pengelolaan dana zakat produktif yaitu, dari pihak LAZISNU bekerja sama dengan ranting desa dalam pendistribusian dana zakat produktif. Mustahiq tidak mendapatkan kwitansi atau tanda bukti penerimaan dana dan hanya dilakukan pencatatan dari pihak ranting desa.

Pengelolaan zakat produktif dalam LAZISNU Kudus dilakukan pendistribusiannya hanya secara langsung berupa uang tunai yang diberikan kepada mustahiq 


\section{Ahmad Thoharul}

penerima zakat yang dijadikan sebagai modal usaha. Nominal dana zakat yang diberikan sesuai dengan kebutuhan mustahiq agar memperoleh laba dari usaha tersebut.

Menurut Arif Mufraini dalam Siti Zalikha menyebutkannya dengan istilah produktif tradisional, pendistribusian dalam bentuk ini terdiri dari dua model yaitu (Zalikha, 2014: 308-309):

a. Zakat yang diberikan berupa uang tunai atau ganti dari benda zakat yang dijadikan sebagai modal usaha. Nominalnya disesuaikan dengan kebutuhan mustahiq agar memperoleh laba dari usaha tersebut.

b. Zakat yang diberikan berupa barang-barang yang bisa berkembangbiak atau alat utama kerja, seperti kambing, sapi, alat cukur, mesin jahit dan lain-lain.

Zakat produktif harus diatur sedemikian rupa, sehingga jangan sampai sasaran dari progam tidak tercapai. Pengelolaan dana zakat produktif, pendistribusiannya pihak LAZISNU memperhatikan orang-orang yang akan menerimanya, apakah dia termasuk orang-orang yang berhak menerima zakat dari golongan fakir miskin, demikian juga termasuk orang-orang yang mempunyai keinginan kuat untuk bekerja dan berusaha. Dalam kaitannya dengan zakat produktif, proses tersebut harus meliputi perencanaan, pengorganisasian dan pengawasan.

Dalam hal perencanaan (planning), LAZISNU Kudus merencanakan suatu tindakan tentang apa saja yang akan dilaksanakan untuk tercapainya program. Awal pemberian modal usaha kepada masyarakat, LAZISNU Kudus melakukan survei ke lapangan dan melakukan sosialisasi program dengan calon penerima untuk menyamakan persepsi dan program. Sedangkan dalam hal pengorganisasian (organizing), LAZISNU Kudus bekerjasama dengan MWC dan ranting di dalam wilayah 
kerja kecamatan-kecamatan. LAZISNU sebagai pemberi arahan kepada MWC dan ranting, dimana MWC dan ranting sebagai pelaksana dari arahan yang diberikan oleh LAZISNU. Dalam pengumpulan dana dilakukan oleh MWC dan ranting kemudian diserahkan kepada LAZISNU sebesar $20 \%$ dari jumlah total yang dikumpulkan masing-masing MWC dan ranting. Pihak MWC dan ranting juga melakukan pendataan kepada semua mustahiq yang ada, kemudian direkomendasikan kepada LAZISNU untuk diseleksi sebagai pertimbangan untuk mustahiq yang perlu disantuni dana zakat produktif.

Dalam hal penggerakan (actuanting), setiap MWC dan ranting melaksanakan tugas masing-masing dengan arahan dari LAZISNU Kudus, diantaranya: (1) Pendataan data mustahiq, dengan dilanjutkan penyeleksian calon penerima zakat produktif. (2) Setiap MWC dan ranting memberikan hasil pengumpulan dana sebesar $20 \%$ yang akan diserahkan ke LAZISNU Kudus. (3) Penyaluran modal untuk usaha produktif dilakukan di kantor LAZISNU Kudus atau di lokasi kecamatan serta lokasi usaha mustahiq penerima zakat produktif.

Pengawasan (controlling), kegiatan pengawasan yang dilakukan secara berkelanjutan oleh LAZISNU Kudus untuk mengetahui perkembangan usaha yang dikelola mustahiq. Dalam hal ini, pengelola LAZISNU mengevaluasi kinerja mustahiq secara periodik. Pengawasan juga dilakukan untuk mengamati potensi atau kemungkinan bertambahnya penduduk miskin (adanya mustahiq baru). Sesuai dengan hasil wawancara dengan bapak Sya'roni Suyanto selaku ketua LAZISNU Kudus, bahwa pengawasan dan evaluasi mencakup pengawasan terhadap perkembangan usaha mustahiq, kendala yang dihadapi, dan tercapainya target pemberdayaan dengan indikator terjadinya perubahan status dari mustahiq menjadi muzakki. 


\section{Ahmad Thoharul}

\section{Pengelolaan zakat produktif LAZISNU untuk pemberdayaan masyarakat}

Zakat produktif untuk pemberdayaan ekonomi mustahiq yang dilakukan LAZISNU Kudus adalah dengan program zakat produktif. Program ini diarahkan untuk membantu masyarakat dalam membangun perekonomian guna menompang kebutuhan hidup sehari-hari dan juga meningkatkan taraf hidup. Ini dilakukan agar kaum dhu'afa bisa diberdayakan dan tidak diberi santunan atau zakat secara terus menerus. Selain itu harapan ada peningkatan dari mustahiq menjadi muzakki.

Pemberdayaan ini dimaksudkan untuk berkuasa atau mampu atas dirinya sendiri untuk memenuhi kebutuhannya. Pemberdayaan masyarakat adalah proses pembangunan di mana masyarakat berinisiatif untuk memulai proses kegiatan sosial untuk memperbaiki situasi dan kondisi diri sendiri (wikipwdia.com).

Kegiatan pemberdayaan tersebut dengan memberikan dana zakat untuk usaha produktif supaya dapat memberikan semangat kepada para mustahiq yang kekurangan modal usaha, sehingga dengan bantuan tersebut dapat memberikan motivasi serta dapat membangkitkan semangat masyarakat untuk berhasil.

Menurut Sartika dalam Nasrullah, dana zakat untuk kegiatan produktif akan lebih optimal bila dilaksanakan oleh lembaga amil sebagai organisasi yang terpercaya untuk pengalokasian, pendayagunaan, dan pendistribusian dana zakat, mereka tidak memberikan zakat begitu saja melainkan mereka mendampingi, memberikan pengarahan serta pelatihan agar dana zakat tersebut benar-benar dijadikan modal kerja sehingga penerima zakat tersebut memperoleh pendapatan yang layak dan mandiri (Nasrullah, 2015: 12). 


\section{Zakat Produktif untuk Pemberdayaan Ekonomi ...}

Kegiatan pemberdayaan berikutnya adalah pembinaan dan pendampingan. Pembinaan diarahkan pada aktivitas koordinasi dan konsultasi. Koordinasi dan konsultasi difokuskan pada pengidentifikasian jenis usaha yang sesuai dengan potensi mustahiq, perumusan strategi bisnis, model pengelolaan usaha, managemen keuangan, managemen sumber daya manusia, hingga membangun akses kelembaga pembiayaan. Dengan demikian para mustahiq dapat mengambil keputusan yang lebih tepat terkait dengan rencana usaha yang akan dirintis. Ketika usaha yang dirintis dan dikelola mustahiq beroperasi dan menunjukkan perkembangan atau kemajuan usahanya. Pembinaan sendiri dilakukan satu kali pada waktu sosialisasi penyerahan dana produktif di LAZSINU Kudus. Seharusnya sosialisasi dilakukan setiap satu bulan sekali agar usaha mustahiq dapat berkembang.

Kegiatan berikutnya adalah pendampingan, kegiatan ini bertujuan untuk memberikan berbagai alternatif solusi berkenaan dengan pengoperasian dan penyelesaian kendala usaha yang dihadapi oleh kelompok usaha mustahiq. Dan kegiatan pemberdayaan yang terakhir yaitu kegiatan pengawasan dan evaluasi kinerja mustahiq. Kegiatan pengawasan tidak dilakukan setiap sebulan sekali. Evaluasi yang dilakukan LAZISNU Kudus tidak begitu efisien, dikarenakan tidak dilakukan evaluasi secara rutin. Evaluasi dilakukan oleh pengurus LAZISNU tanpa mengundang pengurus $\mathrm{MWC}$, pengurus ranting dan pengurus JPZIS.

Kegiatan pendataan, pembinaan, pendampingan dan pengawasan tersebut diperlukan dalam penyaluran zakat secara produktif juga dapat menghilangkan sifat bermalasmalasan dengan hanya mengharapkan bantuan dari orang lain. Sehingga dapat menciptakan sebuah mata pencaharian yang akan mengangkat kondisi ekonomi para mustahiq, sehingga diharapkan lambat laun mereka akan dapat keluar dari jerat kemiskinan, lebih dari itu mereka dapat 


\section{Ahmad Thoharul}

mengembangkan usaha sehingga dapat menjadi seorang muzakki.

Dengan berkembangnya usaha kecil menengah dengan modal berasal dari zakat akan menyerap tenaga kerja. Hal ini berarti angka pengangguran bisa dikurangi, berkurangnya angka pengangguran akan berdampak pada meningkatnya daya beli masyarakat terhadap suatu produk barang ataupun jasa, meningkatnya daya beli masyarakat akan diikuti oleh pertumbuhan produksi, pertumbuhan sektor produksi inilah yang akan menjadi salah satu indikator adanya pertumbuhan ekonomi. Dengan gambaran tersebut, maka peranan zakat sangat signifikan dalam kehidupan manusia. Dimana zakat merupakan suatu penggerak atau motor yang berpotensi memberikan tunjangan kepada para pedagang ataupun profesi lain yang membutuhkan modal, yang tidak bisa didapatkan dari jalan lain (Nasrullah, 2015: 12-13).

$\mathrm{Bu}$ Ngatmi adalah salah satu penerima zakat produktif yang sedang berstatus janda, LAZISNU Kudus menyalurkan dana produktif kepada masyarakat miskin dengan prioritas janda miskin yang mempunyai anak banyak sehingga tidak mampu dalam perekonomian. Bantuan diberikan dalam bentuk uang tunai sebagai modal usaha. Janda merupakan sosok perempuan yang tidak bersuami, harus menanggung penderitaan secara fisik dan psikis, dan janda memiliki fungsi dari dua sisi. Disatu sisi sebagai ibu atas keturunannya dan sisi lain sebagai kepala keluarga menggantikan suaminya dimana dia harus menghidupi keluarganya.

Pemberian dana zakat produktif yang ada di LAZISNU Kudus memberikan kontribusi bagi usaha janda miskin, yaitu transformasi mustahiq menjadi muzakki, peningkatan usaha janda miskin dan kemandiran ekonomi. Transformasi menjadi muzakki dibutuhkan rentan waktu 
dan proses yang panjang, dan biasanya bisa dikatakan muzakki jika penghasilanya sudah mencapai nishab. Untuk peningkatan usaha janda miskin setelah mendapatkan dana zakat produktif ini produksi lebih banyak dari sebelumnya. Selain itu kemandirian ekonomi yakni para mustahiq mampu memenuhi kebutuhan pribadi dalam batas mensejahterakan diri, tidak membutuhkan dan tidak bergantung pada orang lain dalam menjalankan persoalan ekonomi.

Berdasarkan fakta yang ditemukan, maka LAZISNU Kudus sudah menerapkan kegiatan pemberdayaan mustahiq dari mulai pendataan, pembinaan dan pengawasan. Dikarenakan kurangnya karyawan di LAZISNU Kudus, sehingga tidak adanya kegiatan pendampingan. Dalam menjalankan program pemberdayaan zakat produktif ini ditujukan bagi pengembangan ekonomi mustahiq melalui pemberian modal usaha. Tujuan dari pemberdayaan zakat produktif ini adalah mentransformasikan dari mustahiq menjadi muzakki.

\section{Kendala dan solusi yang dihadapi LAZISNU Kudus}

Penerapan pengelolaan zakat produktif ini bukan berarti tanpa hambatan dan kendala. Pada praktiknya banyak ditemukan kendala dan permasalahan, mulai dari kendala pengumpulan dana zakat dari muzakki hingga pendistribusian serta pembinaan dan pendampingan sering kali terdapat masalah.

Adapun faktor kendala yang dihadapi LAZISNU Kudus ada dua, yaitu faktor internal dan eksternal. Diantara faktor internal yang menjadi kendala LAZISNU Kudus dalam memberikan dana zakat poduktif untuk modal usaha janda miskin masih sangat kecil. Jumlah dana yang dapat diterima oleh mustahiq maksimal sebesar Rp 1.000.000,-Jumlah nominal tersebut dianggap kurang dalam menambah modal untuk usaha mereka. Hal itu sebagaimana $\mathrm{Bu}$ Ngatmi yang diberikan dana zakat 


\section{Ahmad Thoharul}

produktif, dia merasa masih kurang untuk memenuhi kebutuhan modal usahanya yang sedang berjalan.

Jumlah nominal yang masih terbatas tersebut disebabkan oleh kurangnya kegiatan pengumpulan dana. Diharapkan LAZISNU memaksimalkan kegiatan fundraising untuk menambah dana zakat yang terkumpul.

Factor internal lain adalah kurangnya koordinasi. Koordinasi antara LAZISNU Kudus dengan ranting desa menjadi salah satu faktor penghambat dalam pemberdayaan dana zakat produktif. Ranting desa tidak memberikan laporan kepada LAZISNU Kudus secara berkala. Sehingga LAZISNU tidak mempunyai data yang valid tentang kegiatan penerima dana zakat produktif. Lemahnya koordinasi ini disebabkan oleh kurang intensnya koordinasi antara LAZISNU Kudus dengan ranting desa. Kurangnya koordinasi berimbas pada ketidakjelasan dalam menjalankan tugas masing-masing. Maka diharapkan antara LAZISNU dan ranting desa meningkatkan koordinasi secara rutin sehingga dapat memberikan laporan secara berkala.

Factor internal lain adalah kurangnya SDM yang memadai dan juga pengelolaan administrasi yang masih tradisional. Hal ini seperti yang disampaikan oleh Bapak Sya'roni, permasalahan internal yang mendasar terdapat pada kurangnya SDM yang memadai. Kurangnya SDM ini berdampak pada kurang optimalnya pengeloaan zakat produktif. Selain itu, LAZISNU Kudus masih menggunakan cara administrasi yang tradisional yang hanya mencantumkan pemasukan masuk di debit, pengeluaran masuk di kredit, kemudian saldo di akhir. Hal ini dikarenakan LAZISNU Kudus belum menerapkan PSAK 109, yaitu standar penghitungan akuntansi zakat yang dianjurkan oleh Pemerintah.

Diantara faktor eksternal adalah masih banyaknya muzakki yang menunaikan zakatnya di luar lembaga amil. 


\section{Zakat Produktif untuk Pemberdayaan Ekonomi ...}

Menurut Sartika dalam Nasrullah, dana zakat untuk kegiatan produktif akan lebih optimal bila dilaksanakan oleh lembaga amil sebagai organisasi yang terpercaya untuk pengalokasian, pendayagunaan, dan pendistribusian dana zakat, mereka tidak memberikan zakat begitu saja melainkan mereka mendampingi, memberikan pengarahan serta pelatihan agar dana zakat tersebut benar-benar dijadikan modal kerja sehingga penerima zakat tersebut memperoleh pendapatan yang layak dan mandiri (Nasrullah, 2015: 12).

Dari teori diatas mengungkapkan bahwa dengan adanya LAZISNU dapat menjadi wadah atau sarana untuk mencapai efisiensi dan efektifitas, serta sasaran yang tepat dalam penggunaan dana zakat menurut skala prioritas. Penyaluran melalui lembaga amil juga dapat digunakan untuk kemaslahatan umat Islam secara umum yang memerlukan dana yang tidak sedikit. Sehingga zakat diserahkan langsung dari muzakki kepada mustahiq, meskipun secara hukum syari'ah adalah sah, akan tetapi tidak akan tepat sasaran, terutama yang berkaitan dengan kesejahteraan umat secara umum akan sulit diwujudkan. Oleh karena itu, membayar zakat kepada lembaga amil adalah cara yang efektif dikarenakan lembaga amil zakat mempunyai data mustahiq yang membutuhkan santunan dana.

Factor eksternal lain adalah kurangnya pengetahuan mustahiq tentang manajemen usaha. Banyak dari mustahiq yang belum bisa memanaj usahanya dengan baik. Hal ini dikarenakan pendekatan dari pihak LAZISNU Kudus dalam mengelola zakat produktif kurang maksimal. Permasalahan tersebut dapat diatasi dengan penyaluran zakat produktif disertai bantuan pendidikan. Hal tersebut menjadikan mustahiq memiliki kemampuan untuk lebih meningkatkan pengetahuan (keilmuan) dalam mensejahterakan hidupnya yang sebelumnya terkendala oleh pengetahuan dan modal 


\section{Ahmad Thoharul}

usaha. Selain itu juga dapat memberikan program kemitraan dengan kegiatan usaha yang telah beroperasi, dengan tujuan untuk memberikan pemahaman kepada mustahiq mengenai pengetahuan berwirausaha dan meningkatkan ketrampilan para mustahiq. Pengetahuan dan ketrampilan tersebut kemudian dapat digunakan oleh para mustahiq untuk merintis usaha secara mandiri.

\section{Simpulan}

Zakat produktif harus diatur sedemikian rupa, sehingga jangan sampai sasaran dari progam tidak tercapai. Pengelolaan dana zakat produktif, pendistribusiannya pihak LAZISNU memperhatikan orang-orang yang akan menerimanya, apakah dia termasuk orang-orang yang berhak menerima zakat dari golongan fakir miskin, demikian juga termasuk orang-orang yang mempunyai keinginan kuat untuk bekerja dan berusaha. Kaitannya dengan zakat produktif, proses tersebut harus meliputi perencanaan, pengorganisasian, penggerakan dan pengawasan.

Zakat produktif untuk pemberdayaan ekonomi mustahiq yang dilakukan oleh LAZISNU Kudus dengan program zakat produktif, dengan diarahkan untuk membantu masyarakat dalam membangun perekonomian guna menompang kebutuhan hidup sehari-hari dan juga pengalokasian zakat produktif dilakukan untuk meningkatkan taraf hidup. Ini dilakukan agar kaum dhu'afa bisa diberdayakan dan tidak diberi santunan atau zakat secara terus menerus. Selain itu harapan ada peningkatan dari mustahiq menjadi muzakki. Adapun langkah-langkah pemberdayaan, yaitu pendataan, pembinaan, pendampingan, dan pengawasan. 


\section{Zakat Produktif untuk Pemberdayaan Ekonomi ...}

Penerapan pengelolaan zakat produktif ini bukan berarti tanpa hambatan dan kendala. Pada praktiknya di lapangan banyak ditemukan kendala dan permasalahan. Mulai dari kendala pengumpulan dana zakat dari muzakki hingga pendistribusian serta pembinaan dan pendampingan sering kali terdapat masalah. Adapun faktor kendala yang dihadapi LAZISNU ada dua, yaitu faktor internal dan eksternal.

\section{Daftar Pustaka}

Achmad Syaiful Hidayat Anwar, Model Pemberdayaan Ekonomi Mustahiq Melalui Zakat, JEAM Vol. XV, 2016.

Arief Mufraini, Akuntansi dan Manajemen Zakat, Kencana Prenada Media Group, Jakarta, 2006.

Dzari'atus Sanihah, Pengelolaan Dana Zakat (roduktif Untuk Pemberdayaan UMKM (Studi Kasus pada Rumah Zakat Kota Malang), Jurnal, Malang, 2014.

Hasbi, Pedoman Zakat, Semarang, PT. Pustaka Rizki Putra, Semarang, 2002.

Hasibuan, Manajemen: Dasar, Pengertian, dan Masalah, PT Bumi Aksara, Jakarta, 2015.

https://id.wikipedia.org/wiki/Pemberdayaan_masyarakat diakses pada tanggal 05 maret 2018 pukul 09.25 WIB

Ibnu Hajar al-Asqalani, Bulughul Maram \& Dalil-Dalil Hukum, Gema Insani, Jakarta, t.th.

M. Yasir Yusuf, Zakat Produktif: Merubah Mustahik Menjadi Muzakki, (Online). Tersedia: http:// www.baitulmal.acehprov.go.id/?p=2058 November 2017). 


\section{Ahmad Thoharul}

Muhammad Syaikh, Fatwa-Fatwa Zakat, Darus Sunnah Press, Jakarta, 2008.

Muhammad Hasan, Manajemen Zakat Model Pengelolaan Yang efektif, Idea Press, Yogyakarta, 2011.

Narullah, Regulasi Zakat dan Penerapan Zakat Produktif Sebagai Penunjang Pemberdayaan Masyarakat (Studi Kasus Pada Baitul Mal Kabupaten Aceh Utara), Jurnal Penelitian Sosial Keagamaan, Vol. 9 No. 1, Aceh, 2015.

Nurul Huda dkk, Zakat: Perspektif Makro-Mikro (Pendekatan Riset), Prenamedia Group, Jakarta, 2015.

Siti Zalikha, Pendistirbusian Zakat Produktif Dalam Perspektif Islam, Jurnal Ilmiah Islam Futura, Vol. 15 No. 2, Bireuen, 2016.

Toriquddin Moh, Pengelolaan Zakat Produktif di Rumah Zakat Kota Malang Perspektif Maqashid Al Syariah Ibnu 'Asyur, di Kabupaten Malang, Volume.16 No.1 Maret 2015.

Wahbah Al-Zuhaily, Zakat: Kajian Berbagai Mazhab, Agus Effendi, Bahruddin Fannany terjemah, PT. Remaja Rosdakarya, Bandung, 2008.

Zaenal Mukarom, Manajemen Pelayanan Publik, CV Pustaka Setia, Bandung, 2015. 